\title{
“Tjap Go Meh" Introduction of Acculturation as Mutual Respect for Society
}

\author{
Ira Wirasari $^{1 *}$, Dimas Krisna ${ }^{1}$, Novian Denny Nugraha ${ }^{1}$, Anggar Erdhina ${ }^{1}$, Sakina Fathiani ${ }^{1}$, Moh Farhan ${ }^{2}$ \\ 1.Telkom University, Indonesia \\ 2.Universiti Teknologi Malaysia, Malaysia \\ *e-mail: irawirasari@telkomuniversity.ac.id
}

\begin{abstract}
Lontong Tjap Go Meh is one of the most popular Chinese half-state dishes in Indonesia. Initially, this dish was served at the Tjap Go Meh celebration, which is the celebration of the fifteenth day of the Chinese new year. In further developments, we can enjoy this dish every day. Uniquely, this dish is actually not found in China. The similarity with Ketupat Lebaran, has a connection with the spread of Islam in Java and acculturation with the local culture. We can find a similar dish in Malaysia, Laksa. Unfortunately, not many people know about the origin and philosophy of this dish. In the Chinese community in Indonesia itself, many Chinese people, especially the younger generation do not know the history behind the lontong Tjap Go Meh, except as a dish passed down by the previous generation. Tjap Go Meh's celebration in Indonesia can be said as something new for them, especially since this celebration was banned during the New Order regime. This cultural-based research intends to reintroduce the origins and philosophy of Lontong Tjap Go Meh through media that can be enjoyed by the younger generation, namely short animation. With qualitative research, and supported by observational data collection, literature study and interviews with Chinese cultural figures, it is hoped that the messages to be conveyed through character and setting designs can be effectively received.
\end{abstract}

Keywords: Tjap Go Meh, Chinese Culture within South East Asia, Chinese half-state.

DOI: $10.7176 / \mathrm{ADS} / 99-01$

Publication date: February $28^{\text {th }} 2022$

\section{INTRODUCTION}

Lontong Tjap Go Meh is one of the most famous Chinese half-state's culinary in Indonesia. Lontong Tjap Go Meh is also one form of acculturation from the culinary culture of the archipelago and also Chinese culture in the form of culinary culture. Everybody in Indonesia, especially the Chinese half-state community must know the taste of this unique dish well. Contrary with the dish, not everyone in Indonesian know about the historyand the origins behind the dish. In fact, event in China, there's no dish that similar with Lontong Tjap Go Meh itself. Lontong Tjap Go Meh has the similar components as Ketupat Lebaran, the famous dish that serves in Idu1 Fitri's celebrations. The dish contains solid steamed rice blocks mixed with chicken curry which serves with marrow slice, bean sprout and fried shallots and crackers. In Malaysia and Singapore, the dish is very similar with their Laksa. The similarity components and the philosophy with the Ketupat Lebaran (Which also didn't exist in Arab and other Middle East Countries, except the curry), made the two dishes are parts of Indonesian people's traditional culinary assets that came from two different custom and religion's assimilation.

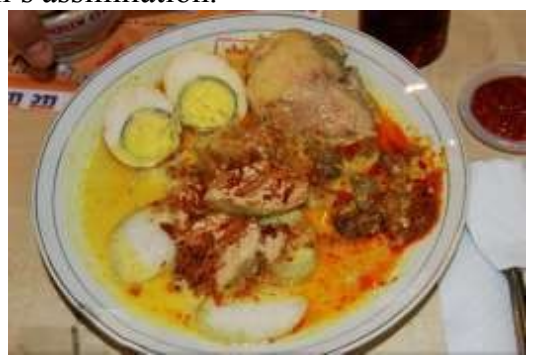

Figure 1. Lontong Tjap Go Meh

Source: Batamclick.com

Some of its origins told that the two dishes were introduce by one of, Sunan Kalijaga who his name revealed as Gan Si Cang, ( NJ), one of the Muslim's Nine Apostles or Wali Sanga who spread Islam in Java Island. Sunan Kalijaga is one of the Nine Apostles, who used the cultural and the acculturation approach during his missionary to spread Islam, such as Wayang Kulitf Shadow Puppet. Tjap Go Meh term itself referred to Hokkian's people to the $15^{\circ}$ dayoftheLunarNew Year[InChinese, Tjap Go Meh called as Yuan Xiao Jie (N)].

In traditional Chinese custom, in the $15^{*}$ day, the Chinese should serve rice balls or rice cakes. Lontong or the rice blocks itself was believed adapted from the traditional rice cakes. But, to honor the native Muslims Community, the Chinese serve this rice blocks with the Chicken Curry called Opor Ayam. The similar dishes It's a pity that for very long time, the reference and literacy about how the Chinese affected the Indonesian's Muslims' 
custom and the opposites were difficult to find, due the Soeharto's New Order regime banned all of the Indonesian Chinese's literacy during his triumphant

The origins and history about the Lontong Tjap Go Meh and the celebration of Lunar Year in Indonesia would be a good narration to tell for the generations, especially for the children, so they could learn the Plurality of the Indonesian, and also grow their respects and honor to the other religions and cultures, as the part of the nationalism insight.

\section{The Benefit and The Goal of the Research}

The birth of the media such as comics, animations and games could be exploring as media for the youngsters to tell the history and the origins of Lontong Tjap Go Meh as part of Indonesian culture, especially because it came from the Chinese half-state community in Java. This issue is important, because of the conditions in Indonesia in nowadays. The political conflicts after the general elections for past five years bring the bond of the plurality to the horizontal conflicts, which lead to the in group exclusivity, discriminations and racism more sharp than what happened during the New Order regime. The Research see that, the media such as animations could educate the young generations to learn that Indonesia, as a nation state building built from many cultural values, customs and also the people. Animation characterization, which drawn in cartoon style has the universal visual language and could bring the message about the plurality issue in safe way and also could be understand in visual look, gestures and its traits comfortably.(McCloud, 1994)

Therefore, the research would like to developed a visualization trait such as characters and background design based on animated aesthetics. The deformation and simplicity look from the character and background design could use to bring the message about the origins of the Lontong Tjap Go Meh in an edutainment media.

Based on the above description so the research problems for the study are:

1.How animation assets such as character and background's design content be made by adopting the history and the origins of the Tjap Go Meh celebration as animation feature?

2. How the concept art could be made into something that delivered the values of the origins of Lontong Tjap Go Meh animation that accepted by target audience?

\section{LITERATURE REVIEW}

In this research and observation, there are several reviews of books that strengthen the statements about the values within Lontong Tjap Go Meh. First book is coming from Aji Bromokusumo that compare between Lontong Tjap Go Meh and Ketupat Lebaran. The interesting fact, that either lontong and ketupat shared same the way of making the rice blocks and the philosophy inside. The rice blocks were cooked by covered the rice in leaves lontong use banana's leaves, in the other hand, ketupat covered by coconut's leaves]. After it get cooked, the leaves some marks some rough textures, which the philosophy told as the burden of life that must carry to the people, it also resembles the philoshopy of the tough life that must face by human being. Then after we chopped the rice block inside, we will find the middle of the rice block is all white and tender, that symbolized the inside the human heart as a pure heart.

Meanwhile, the other dishes that serve with the lontong also have the philosophies which the Chinese had believed and put their faith, such as: 1) opor Ayarn, with yellow curry soup that symbolized as gold color, which believed to bring wealth. 2) Sambal goreng Kentang, a variation of chili paste with fried potato blocks and liver paste that symbolized as red color, which believed to bring luck and prosperity. 3) The long shape before it chopped off from the lontong also symbolized as long 1ive.(Bromokusumo, 2013)

The second book is from Tan Chee-Beng, who wrote about the culinary culture within the Chinese overseas and Chinese half-state in South East Asia. The book also referred about the relations between Chinese culinary culture that assimilate with local wisdom that created new halfbreaded dishes and its values especially with the Muslims Community in Indonesia and Malaysia.(Beng, 2013).

The third book, maybe not tell us about the dishes, but Benny G. Setiono wrote about the history about the Chinese communities' influence in politics, economics and culture. In this book we could find the origins about Gan Si Kang, who later became Sunan Kalijaga and also the history about the admiral Zhang He's expedition and the spread of Islam in Java (Setiono, 2003). Some of books also used to get the references about the values that Sunan Kalijaga brings with the culture and some books about Chinese cuisines and festivals references which related with Tjap Go Meh origins.

\subsection{Adaptation Theory}

Based on his research, Kim found that there are two stages of adaptation, namely cultural adaptation and crosscultural adaptation. Cultural adaptation is The basic process of communication is where there is a sender, medium and receiver message, so that the encoding and decoding process occurs. This process is defined as the rate of change that occurs when an individual moves to a different environment new. There is a process of sending messages by local residents in the new environment that can be understood by individual immigrants, this is called enculturation. Enculturation occurs at the time of socialization. 
The second stage is cross-cultural adaptation. Cross-cultural adaptation includes three main things. First, acculturation. This process happens when individual immigrants who have gone through the socialization process begin to interact with a new and foreign culture. As time goes by, The newcomer begins to understand the new culture and chooses norms and values their local culture. However, the previous cultural pattern also affect the adaptation process. Past cultural patterns that also influence this called deculturation which is the second part of the adaptation process.

Change This acculturation affects the psychological and social behavior of the immigrants with a new identity, new cultural norms and values. This is what then triggers the occurrence of resistance to the new culture, so it is not impossible immigrants will isolate themselves from the local population. However, it must be understood again that in the adaptation process there are changed and some did not change. Gudykunts and Kim (2003) stated that the possibility of individuals to change the environment is very small.

That matter due to the dominance of the local culture that controls the continuity of daily life that can force immigrants to adjust. The third thing is the most perfect stage of adaptation, namely assimilation (Gudykunts and Kim, 2003). Assimilation is a state where immigrants minimize the use of old culture so that it looks like local residents. In theory, it seems that assimilation occurs after a change acculturation, but in reality assimilation is not achieved perfectly.

\subsection{Theory of Design Character}

According to Bryan Tillman (2011), in his book Creative Character Design, The story is one part of creating a good character design. Although the story is not the main part in the character design, but the story will help us find and build character through these character traits in the story. So that we will get a strong picture to design that character. And what character designers have to remember is characteralways held to run a story well It's possible to draw a character without a story first, and most people do that all the time.

The problem that happens when it's done, and still wants to use the characters that have been design is when the story doesn't match the character, so have to make rewrite the story and adapt it to the characters that have been created. But animation that tells a story must have at least a protagonist character that attracts the sympathy of the audience. Between the audience and the character is very important especially if the story is based on the character itself. If the viewer finds his nature similar to these characters will usually attract more attention. But in the making the other characters didn't need to pay attention to such a thing. In formation antagonist, for example, we can make the audience will by themselves hate that character.

Characters must be built before, during and after story creation so that more specific and detailed. Can be started from the background of the character, habits, traits,physical form, motivation and relationships. There are things to pay attention to in character development, namely:

1. Name

Naming is one of the most effective ways to develop character because it describes the character itself.

2. Text, narration and speech

Adding text or voice over to the recognition can help providing information

3. Design

The design must be able to explain the nature and behavior of the character itself with just one look.

4. Behavior

Behavior shows the nature, motivation and background of a person character.

\subsection{Design Background Theory}

Background, according to Cantrell and Yates (2012: xiii), is a component that included in the environment that serves to convey information that support the expected mood of the scene, so that a work will be able to fully understood by the viewer. Unfortunately, most multimedia works in Indonesia, such as games and animations, prioritizes character design, and puts design secondbackground. This may be due to the lack of experts in the backgroundso that the background work looks half-assed (Ikin, in Prabowo and Irawan, 2012:1).

\section{RESEARCH METHOD}

Since the research wants to create animation's assets such as characters' designs and backgrounds' designs, the research will use the visual methodology research. Visual terms here, referred to everything that seen and made by human being, such as paintings, drawings, posters, advertisement, and also statues, monuments and constructions. Those things were created by human beings with the messages that could interpreted.(Soewardikoen, 2019). The whole research will use qualitative methods, that need data analysis.

This research is closely related to Animation course and Budaya Nusantara in the Visual Communication Design S1 study program. The characters in this study are one of the subjects in the animation and illustration course. Analysis of Indonesian and Chinese culture is one form of cultural acculturation contained in one of the subjects of the Budaya Nusantara course. It is hoped that this research can help implement research results into 
the enrichment of lecture material and can be used as an evaluation material for future curriculum development. There is some data collecting:

\section{Observation}

Observation includes the activity of paying attention to an object by using all our senses. Aside from being a direct observation, observation can also be done by recording images. (Arikunto, Suharsimi, 2013). The research will observe some objects related to Tjap Go Meh festivals in Indonesia, especially in some place in Java. Any details to Chinese cultures artifacts that related to Tjap Go Meh festivals will observed as data, then will use as visual references.

\section{Literacy Studies}

Literacy studies are conducted to obtain secondary data. Literacy studies are also carried out with a view to getting visual references, both to get references about everything related to the origin and also documentation about Tjap Go Meh in Indonesia and also in Southeast Asia, especially Malaysia, which has similarities with us. Visual references in this study are not only in the form of photographic recording data, but also the work of several character designs and settings from a number of comics and animations.

\section{Research Chart:}

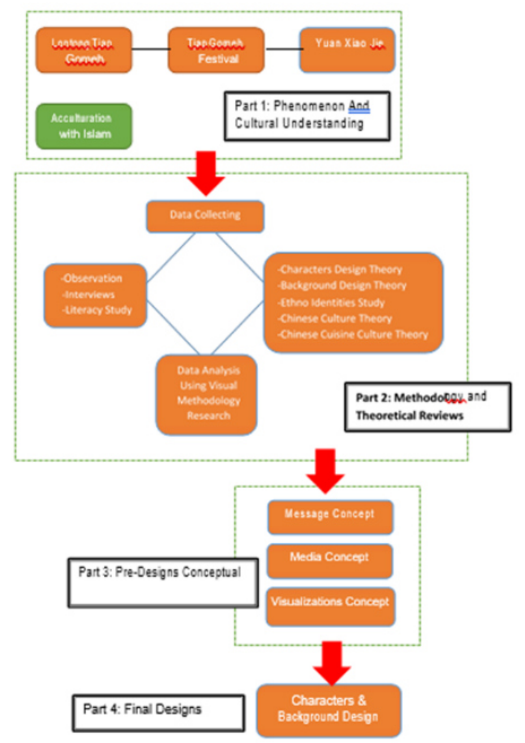

Figure 2. Research Chart

\section{RESULT AND DISSCUSIONS}

As in the research questions above, this section will show the results and processes of character and background design developed from the narrative needs of Tjap Go Meh, as shown in the research diagram in the previous chapter where data shows that Tjap Go Meh or the Lantern Festival can traced back to the Han Dynasty (206 BC to $220 \mathrm{AD}$ ), when Buddhist monks lit lanterns on the 15th day of Chinese New Year in honor of the Buddha. Then spread throughout Asia and the world and have undergone adaptation according to their respective regions. In Indonesia, this celebration will be found differently in various regions and adapted to local culture. but in general it will present Lontong as a Culinary culture of this Tjap Go Meh celebration.

In the context of character and background design, adaptation theory uses adaptation theory from Matthew T. Jones which divides visual narrative adaptation into two parts, namely structural adaptation and thematic adaptation. This design uses a thematic adaptation approach in this case using visual elements of Indonesian Islamic culture (Nusantara) as an integrated part of contemporary Indonesian society.

The operating scheme of the thematic adaptation theory and structure will be shown in the following chart: 


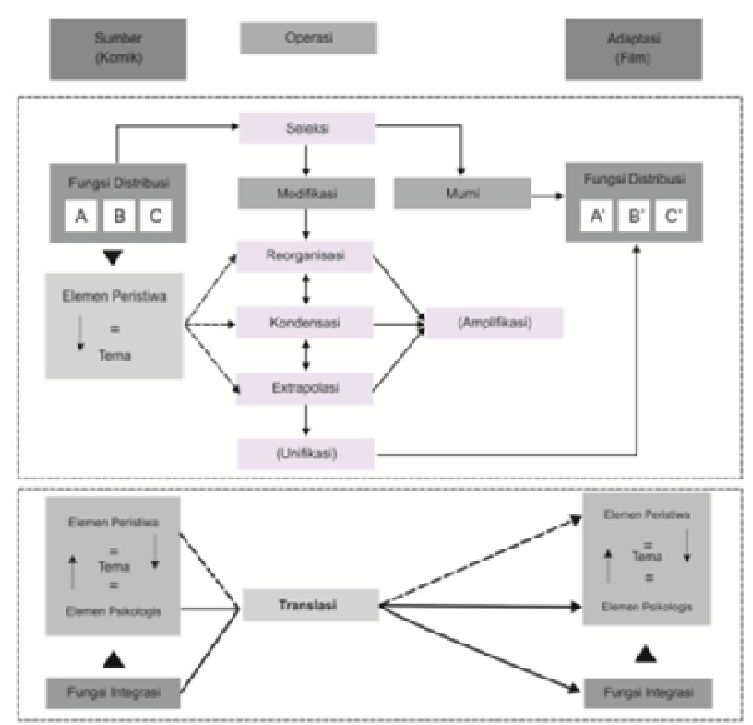

Figure 3. The operating model of adaptation theory developed from the theory of Mathew Jhone modified by Sophia Purbasari for research needs.

The chart shows that the thematic adaptation operation in this case is Modification, which can be developed into several parts, namely Reorganization, Condensation, Extrapotation and Unification, all of which are ultimately needed for distribution or publication needs of the adapted media. This process (thematic adaptation) requires elements as a translation effort in the form of event elements or thematic elements which eventually become big themes or ideas that can be developed in character designs or background designs that are the outputs of this research.

According to Liliweri (2005:140) adaptation is the process of adjusting values, norms and patterns of behavior between two cultures or more. It is assumed that if there are two or more race or ethnicity meet, it will adaptation process occurs. The process itself preceded by the first contact and contact further. The first contact is a problem that immigrants must face in destination, because it is dealing with a society with a culture that different. What's likely to happen when dealing with different cultures is intercultural conflict. From the explanation in above, researchers can draw conclusions that cultural adaptation is a process adjustment of someone different culture with other people. Adaptation process culture can also occur in values, norms in a group certain to other groups.

When referring to the basic visual elements of Tjap Go Meh culture and Islamic culture as one of the cultural elements of contemporary Indonesian society which is the target of distribution or publication of this animated media, it will be seen in the following sections:

\begin{tabular}{|c|c|c|c|}
\hline No & Visual Element Tjap Go Meh & No & Visual Element Islamic Culture \\
\hline 1. & Colors: Red, Gold, Yellow and Black) & 1 & Colors: Green and White \\
\hline 2. & $\begin{array}{l}\text { Artefacts: Chinese Hokian clothes, lanterns, } \\
\text { dragon incense, temples, Chinese architecture, } \\
\text { Chinese specialties, firecrackers }\end{array}$ & 2 & $\begin{array}{l}\text { Artefacts: Muslim clothes, skullcaps, } \\
\text { headscarves/hijabs, rice cakes, rice cakes, } \\
\text { mosque architecture and other Islamic } \\
\text { architecture, prayer beads, firecrackers. }\end{array}$ \\
\hline No & Psychology Element Tjap Go Meh & No & Psychology Element Islamic Culture \\
\hline 1 & $\begin{array}{l}\text { Sacred but Cheerful Magical Atmosphere } \\
\text { Cheerful, Friendly, Crowded, togetherness } \\
\text { Respect, Appreciate, Hope, Joy }\end{array}$ & 1 & $\begin{array}{l}\text { Sacred but Cheerful Magical Atmosphere } \\
\text { Cheerful, Friendly, Crowded, togetherness } \\
\text { Respect, Appreciate, Hope, Joy }\end{array}$ \\
\hline
\end{tabular}

By looking at the event elements and psychological elements described above, the following visual references will be found: 


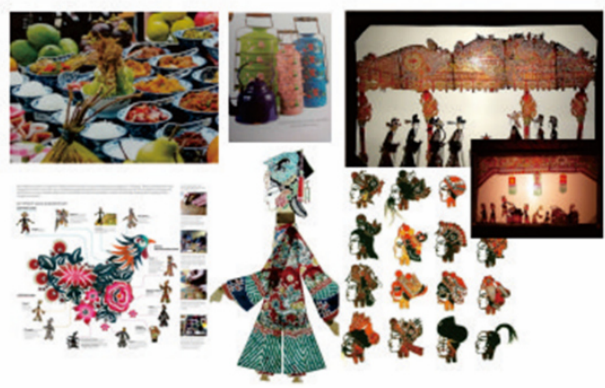

Figure 4. Tjap Go Meh's visual reference (collection of researchers from various sources)
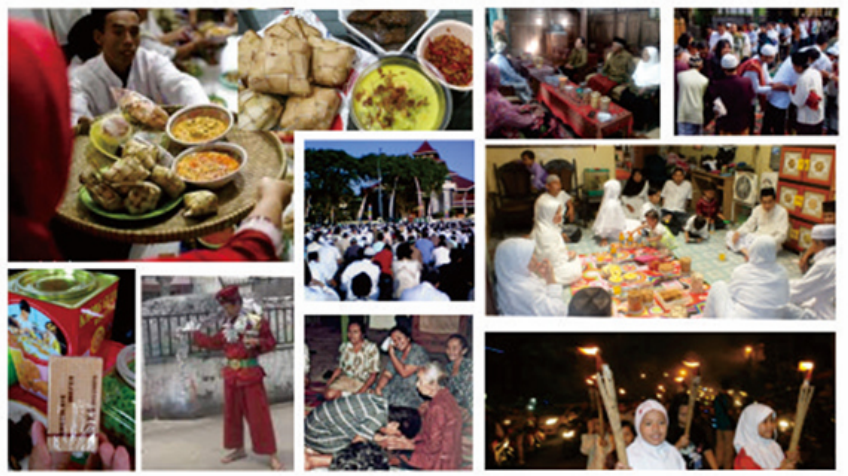

Figure 5. Visual reference for Eid events (collection of researchers from various sources)

\section{The Narrations and Media}

The new narrations of the animations will contain about a small family Indonesian-Chinese Peranakan reunion in the celebration of $15^{\text {th }}$ day of the Lunar New Year in pandemic era. The small family have chat in dining table, discussing about the history about the dishes that served in the table. Than the story moves backward to how the Chinese overseas came to Nusantara and made good relationship with their fellow Muslims native, and the dishes was introduced.

This narrative about family life is a narrative that is very close to the communal life of Indonesian society. Carrying the principle of togetherness called "Gotong Royong". So that the values regarding cultural acculturation are expected to be conveyed well to the target audience. The communication approach carried out with humorous and happy techniques is expected to facilitate the entry of the message.

A family can also be a group of people who are bound by marriage, birth or adoption who live in the same household. Where the family can be formed because of the blood relationship and emotional ties between each individual as a member of the family. Well, in that inner bond, of course, we appreciate each other. So that the understanding and delivery of the history of Lontong TJap Go meh can be well received by the younger generation or the next generation.

The first time humans experience the process of socialization in the family. The family as a unit consisting of father, mother and children. Even though it is a small group, the role of the family is very important in the socialization process. As a social group, the family has values and norms. These values and norms are the first to be socialized to a newborn child. The family is the first medium in the socialization process that has many roles, namely training self-control, understanding social values and norms, and training children in learning social roles. With these considerations and also based on the results of the researcher's observations, the narrative about this family was chosen as the narrative that will be used in making this animation. Therefore, the characters and backgrounds created are also the characters in the family and the atmosphere of the Indonesian people living in the city of Semarang, who are Chinese and Indonesian peranakan families.

There will be two type of animation style that use in the project, first the usual 2D animation that commonly used in children animation to illustrate the today's situations and 2D animation based on the Chinese puppet and Javanese Shadow puppet to illustrated the past scenes. The collaboration between the two styles are considered to delivered the message that we should remember and respect to the past and learn how our ancestors pay respect to others and how they established the values of tolerance and how the diversity builds our customs.

One alternative effective learning media that can be used is animated video. Animated video itself is a 
moving image that comes from a collection of various objects that are specially arranged so that they move according to a predetermined path at any given time. The objects in question are pictures of humans, written texts, pictures of animals, pictures of plants, buildings, and so on.

Talking about the effects of animated videos, of course, not just talking about the appearance in mass media such as television. It's more useful than that. Especially at this time, the era has entered the digital era and of course requires all sectors to be able to make the best use of existing digital technology. So that the animation media can be used as a medium for delivering messages in this study.

\section{Character and Background Design}

Character development and background will be described below. The resulting character is the result of analysis of data collection and observation. The definition of character in films is generally the same as the understanding of literary works, in which it has narrative elements and depictions of a character visually. In the world of literature, according to Jones in Burhan, character/character is a form of painting a clear picture of someone who featured in a story. Burhan emphasized that the story character occupies a strategic position as a carrier and a messenger (mandate,morals) or something that is intentionally conveyed to the audience (Burhan,2006:17).

Character is the distinctive values, both character, character or personality of a person which is formed from the results of internalizing various policies that are believed and used as a way of viewing, thinking, acting, speaking and behaving in everyday life.

From the character that exists in humans, there are character values based on culture and nation such as religious, honest, tolerance, discipline, hard work, creative, independent, democratic, curiosity, national spirit, love for the homeland, respect for achievement, friendly or communicative, peace-loving, fond of reading, environmental care, social care, and responsibility.

The character's designs are the essential parts of the animations, because it brings the soul of the animations. Therefore, the characters' designs are based from real Chinese descents family in Indonesia just like what we see in our daily life. The characters created are the result of data collection methods, namely observation and literature study. Where researchers study the physical characteristics of Indonesians who are of Chinese descent. The physical characteristics consist of their height, body shape, facial character, eye shape, skin color to their gestures and way of dressing. Based on these observations, the characteristics of the characters used in the animation will be obtained later.

The selected family character consists of the whole family, namely Father (Baba), Mother (Mamah Ayu), son (Koko), daughter (Ayu). Grandma (Mother Kim). The following is the result of character design in this study :

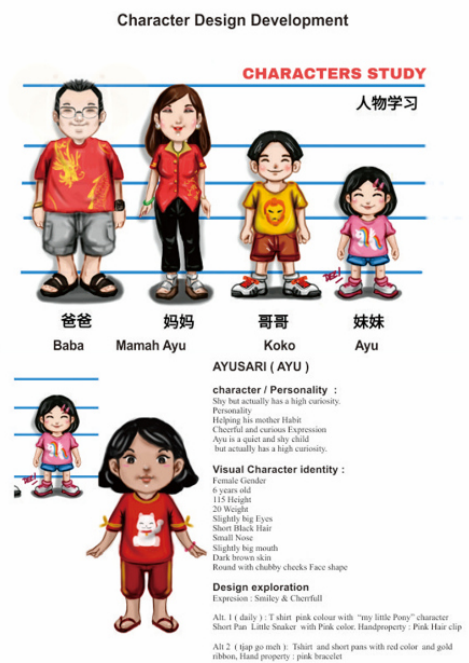

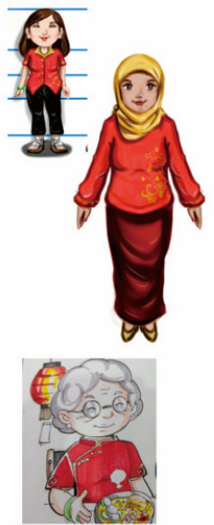
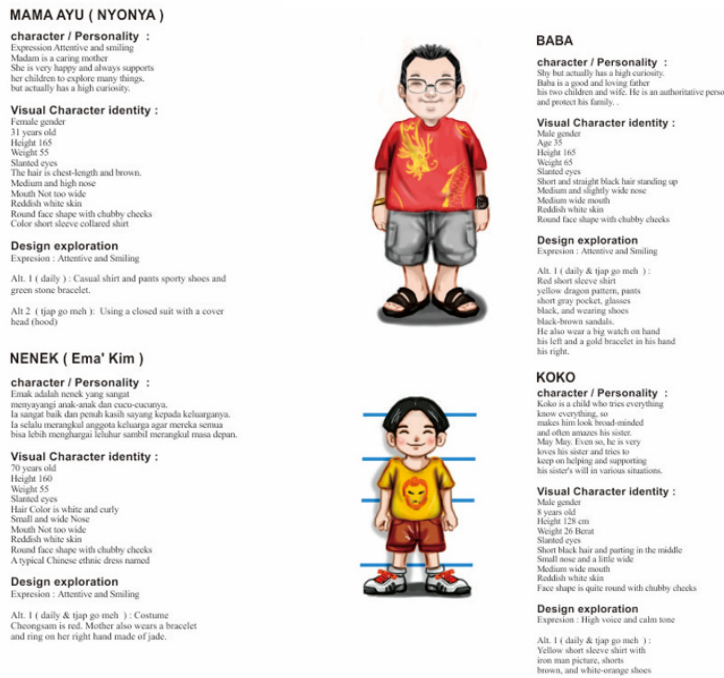

Figure 6. Characters Tjap Go Meh Animation 


\section{Background Design}

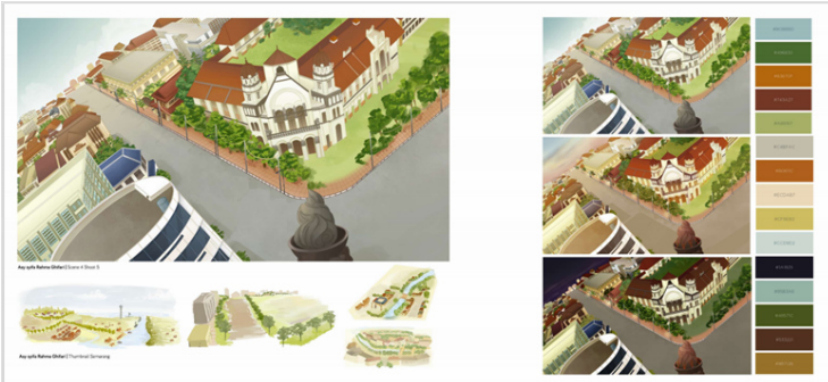

Figure 7. Visual Reference for background

(collection of researchers from various sources)

According to Sudarwani (2012: 97), in macro, the typology of Chinese ethnic houses very obvious and has certain characteristics that easy for people to recognize. Residential symbol ethnic Chinese Semarang Chinatown was formed and is affected by the components: 1. Physical elements, including typology, facades, roofs, ornaments, the color of the house as a main component. Easy Chinese ethnic building physically recognizable, starting from the façade a typical building with a unique roof model curled at the ends. Something special from the roof of a residential house in Chinatown Semarang is to have a bridge that is the influence of the tropical climate. 2. Non-physical elements, including Chinese culture and socio-cultural life as supporting components. Chinese ethnic community in the Chinatown area of Semarang generally have a belief in worshiping gods. In the area there is a temple which is located at skewers that are believed to be able to ward off bad weather in the area and also located in Riverside. At certain times there are rituals of worshiping gods performed at the temple.
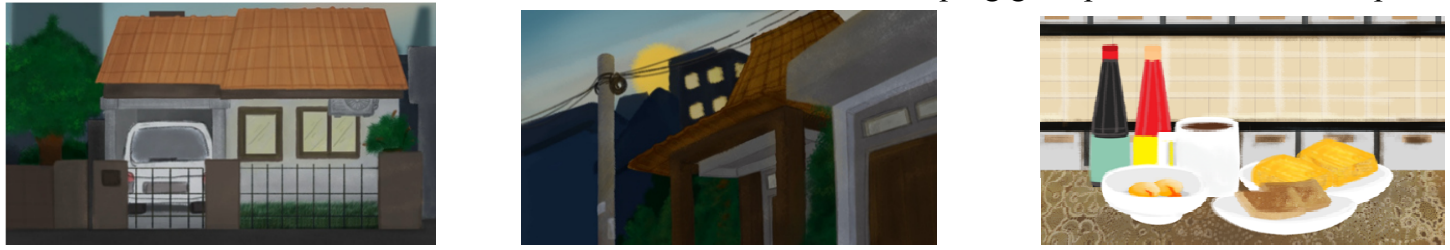

Figure 8. Background design

Source: researcher

Background can be interpreted as a field or gap that looks the farthest when looking at an object. In the field of graphic design, background is a term for the layer that is at the bottom. Background, or what is known as a background, is one of the most important design components. Backgrounds are mainly used to provide a visual decoration to an element, which will result in an increase in the ease of reasoning or understanding of the content.

The background that will be used for this animation is a house in the Semarang area, a city in Indonesia which is the capital city of Central Java. The selection of the background for the use of houses in Semarang is based on the results of observations because Semarang is a part of the area of the Ancient Mataram Kingdom with the name Pragota (now Bergota). Previously this area was a port with a cluster of small islands in front of it due to deposition, the small island group eventually expanded to form a new area which is now referred to as the lower city. From the trade sector, the port is the main heart of trade in Semarang. Along with the development of increasingly large transport ships, the port in Semarang was enlarged and the facilities more complete so that relatively large transport ships could enter the port. With the busier flow of trade through water, more and more traders came either from the Netherlands, China, Malay to Arabic.

Ethnic Chinese first anchored in the city of Semarang, Central Java with the aim of doing trade. They docked in the Mangkang area, West Semarang District, which at that time could be visited by a large ship of the Jonk or Wakang Tjoen type. Currently, the place is a center for industrial areas and factories for various products ranging from food, textiles, metals and other basic necessities. So that's when the assimilation began to occur between ethnic Chinese and the indigenous people of Semarang City. Moreover, some ethnic Chinese men at that time did not bring their wives from China with them. Emergence of ethnic Chinese who are descendants of the original inhabitants of the city of Semarang. Not surprisingly, from then on, several women of ethnic Chinese descent appeared wearing a kebaya, with bun hair (bun) and chewing kinang (betel leaf) like the natives of Semarang City. In addition, at that time, several culinary or cuisines that were identical with the Chinese ethnic nation began to appear, one of which was lontong Tjap Go Meh which was used as the background of the main object in this study.

Based on the results of observations made on houses belonging to Chinese descendants in Semarang, the background results for the house where this character lives are obtained. The city of Semarang was chosen because it is one of the cities that has a history of quite a lot of Chinese. There are various background references that can be used for this animation. "Chinatown in Semarang, is not the same as the Chinatowns in other parts of 
Indonesia. Because they were made and conditioned by the Dutch.

The well-known ethnic Chinese settlements at that time were in the Simongan area, Mangkang area and Ngaliyan area. At that time there was a rebellion against the Dutch carried out by the Dutch. ethnic Chinese. At that time, the ethnic Chinese united with Amangkurat I compactly against the Dutch around the Lasem area, close to Jepara. So it is not surprising that the forerunner of Lasem batik appeared there, "said Semarang historian Jongkie Tio.

\section{Adaptation}

As one of the study topics in this research, the adaptation of Chinese culture into Indonesian culture is a problem that needs to be solved when someone or a group of people communicate with other people from different cultures. Adaptation in this study is generally associated with change of society or part of society. Someone who chooses adaptive strategies tend to have a high awareness of expectations and demands from the environment, so that they are ready to change their behavior, so that cultural assimilation can occur in the visual representation of Tjap Go Meh's character and background.

In the chart above we can map that the beginning of an individual adapting is the enculturation process, namely, the process of learning the cultural values and norms experienced by the individual during his life. This is a very long process and continues throughout human life. This enculturation then enters the next stage, namely acculturation which means a social process that arises when a human group with a certain culture is faced with elements of a foreign culture, and the deculturation process, namely the process of losing old cultural elements to be replaced with elements of a new culture. The cultural process that occurs in the study is acculturation where there is a fusion between Indonesian culture and Chinese culture. So that there is a process of cultural assimilation that is, the process of changing cultural patterns to adapt to the majority. Under such conditions, usually the minority group will gradually lose its identity. This is due to the adjustment process based on intercultural relations and the identity of each culture.

Assimilation is the unification or assimilation of two original cultures into a new culture accompanied by the loss of the original culture. The process of assimilation can occur when members of a group or a community interact intensively directly for a relatively long time.

Then the characteristics of the cultural elements of different groups each change and adapt to each other and produce elements of a mixed culture. It is hoped that the characters and backgrounds that have been created in this research can produce a new cultural element which is a blend of Indonesian and Chinese culture. Based on the results of data observations, it can be seen that the indigenous ethnic group and the Chinese Indonesian ethnic group accept and give each other their culture. Adaptations that occur in the lives of Indonesian and Chinese people have gone well, so with these animated characters and backgrounds, it is hoped that it can provide more understanding for the public that the current culture is a culture resulting from the acculturation of two different cultures, which can provide longer cultural sustainability.

\section{CONCLUSSIONS}

From the results of data gathering and analysis, the results can be concluded as follows. Visual naration can influence behavior, one of which is mutual respect of society, through the development of characters and backgrounds in this visual narrative, it is possible to represent characters who are acculturation of Indonesian and Chinese culture. The characters that have been created consisting of father, mother, son, daughter and grandmother are characters from Indonesian-Chinese families. These characters are used to convey messages about cultural acculturation to the next generation so that they can continue to preserve culture. The character of this family was chosen because the family is the closest thing and is the initial process of learning for humans.

The background of the city of Semarang was chosen because of the Chinese history in the city of Semarang itself and the Tjap Go Meh festival in Semarang. Lontong Tjap Go Meh which is used as one of the objects in this study is also a typical food from Semarang which is the result of a blend of indigenous Indonesian culture with the Chinese community.

These characters and backgrounds can be used to produce an animation with the theme Tjap Go Meh, this animation will tell how from a bowl of Lontong Tjap Go Meh, a long journey about the unification of Indonesian and Chinese cultures can be told. So that it is expected to create a culture of mutual respect and respect in the younger generation. The values and cultural norms that have been carried out by the Indonesian people for a long time will be adapted well and easily by the younger generation through animated media which can also be used as learning media in this digital era. A culture of mutual respect must be built within the framework of Indonesia's development. The culture of mutual respect has been lost. The loss of culture has an impact on the emergence of many problems in society.

Family are the best role models for next generation, because family can practice this attitude of tolerance in their activity of life. Comunity will learn to observe interactions made by their family. Let the comunity relate to diversity. One of the best ways to teach tolerance is to experience it for yourself. Experience can be gained by 
showing example through the media to appreciate and respect others. Provide understanding that we live in a diverse environment. Provide knowledge about diversity and Bhineka Tunggal Ika, as well as Indonesian history.

\section{REFERENCES}

Arikunto, Suharsimi. (2013). Prosedur Penelitian : Suatu Pendekatan Praktik (Edisi Revisi). In Jakarta. Rineka Cipta. Penerbit Rineka Cipta. https://doi.org/10.1017/CBO9781107415324.004

Beng, T. C. (2013). Chinese Food and Foodways in Southeast Asia and Beyond. In Journal of social Issues in Southeast Asia (Vol. 28, Issue 3). NUS Press. https://doi.org/10.1355/sj28-3j

Bromokusumo, A. "Chen." (2013). Peranakan Tionghoa dalan Kuliner Nusantara. In Kompas Media Nusantara. Kompas Media Nusantara.

McCloud, S. (1994). Understanding Comics: The Invisible Art. In Understanding Comics.

Setiono, B. G. 1943-. (2003). Tionghoa dalam pusaran politik. Trans Media.

Gondomono, "Pengantar Untuk Pelangi Cina Indonesia.” PT. Intisari Mediatama, Jakarta, 2002.

B. G. Setiono, Tionghoa dalam pusaran politik. Jakarta: Trans Media, 2003.

A. "Chen" Bromokusumo, Peranakan Tionghoa dalan Kuliner Nusantara. Jakarta: Kompas Media Nusantara, 2013.

D. W. Soewardikoen, Metodologi Penelitian Desain Komunikasi Visual. Jakarta: PT Kanisius, 2019.

Sudarwani, M.M. Simbolisasi Rumah Tinggal Etnis Cina, Jurnal Momentum Vol 8 No.2, Oktober 2021, page 97-112

Suharsimi Arikunto, Prosedur Penelitian Suatu Pendekatan Praktik. Jakarta: Penerbit Rineka Cipta, 2013.

M. Sidharta, “Jejak-jejak Koki Diplomat,” in Etnik Tionghoa di Indonesia, L. Wibisono, Ed. Jakarta: PT. Intisari Mediatama, 2006, pp. 52-61.

KOMINFO, "Penggunaan Internet Naik 40\% Saat Bekerja dan Belajar dari Rumah.” Kementerian Komunikasi dan Informatika RI, Jakarta, 2020.

Liliweri, Alo. 2002. Makna Budaya dalam Komunikasi Antarbudaya. Yogyakarta: LKiS

Agari, Priska, Arief Budiman, "Perancangan Storyboard Untuk Film Animasi 2D Lontong Cap Gomeh," $e$ Proceeding Art Des., vol. 6, no. 3, p. 4050, 2019.

Nopianty, Firda Ayu, Arief Budiman "Perancangan Karakter Untuk Film Animasi Pendek 2d Lontong Cap Go Meh," e-Proceeding Art Des., vol. 6, no. 3, p. 3835, 2019.

A. S. R. Ghifari, "Perancangan Background Untuk Film Animasi Pendek 2d Lontong Cap Gomeh," Universitas Telkom, 2019.

Kim, Young Yun. (2001). Becoming Intercultural: An Integrative Communication Theory and Cross-Cultural Adaptation. USA: Sage Publication.

Tillman, Bryan. 2011. Creative Character Design. Massachusets: Focal Press

Cantrell, Bradley \& Natalie Yates. 2012. Modeling the Environment: Techniques and Tools for the 3D Illustration of Dynamic Landscape Canada : Simultaneously. 